\title{
19 Federalism and the Russian response to the first waves of COVID-19
}

\author{
Nataliya Golovanova
}

\subsection{Introduction}

The COVID-19 pandemic has changed much of the traditional world. At the individual level, personal habits and interactions have changed vastly. At the governmental level in policies around economics, education, and health care, much is different. Federalism has also changed as a result of the pandemic. The emergency management responses to COVID-19 by some governments have involved centralization in decision-making. Many governments have justified such centralized policy choices as the urgent national response of "emergency federalism" (Kurlyandskaya 2020). However, in Russia, powers were already centralized, so there was not much need to change the distribution and balance of powers.

The new revision of the Constitution of the Russian Federation (RF), adopted in the summer of 2020, formally expanded the list of powers of the President. However, centralization occurred much earlier, and the amendments only fixed on paper the already established practices. Over the past decade in Russia, the federal government has strengthened political control over the regions, but the financial levers have always been in the hands of the center.

On the one hand, the central government in Russia issues a large number of regulatory documents: decrees, recommendations, resolutions, bylaws, and orders that subnational governments must follow. On the other hand, regional governments had the right to choose their own instruments for fighting the pandemic. The federal budget generously provided additional transfer payments to the regions, though at the same time, higher rates of cases or high mortality from COVID-19 have been the reasons to blame regional governments directly. COVID-19 has created a new reality in all spheres of our life (Table 19.1).

Table 19.1 Key Statistics on COVID-19 in Russia as of 31 December 2021

\begin{tabular}{lllll}
\hline $\begin{array}{l}\text { Cumulative } \\
\text { Cases }\end{array}$ & $\begin{array}{l}\text { Cumulative Cases per } \\
100,000 \text { Population }\end{array}$ & $\begin{array}{l}\text { Cumulative } \\
\text { Deaths }\end{array}$ & $\begin{array}{l}\text { Cumulative Deaths per } \\
100,000 \text { Population }\end{array}$ & $\begin{array}{l}\text { Case Fatality } \\
\text { Percentage }\end{array}$ \\
\hline $3,159,297$ & $2,156.6$ & 57,019 & 38.9 & 1.8
\end{tabular}

Source: Data source: Yandex DataLens, 2021. All Known Cases in Russia [dataset]. Available from: https://datalens.yandex/covid19 [Accessed 1 February 2021]. 


\subsection{The impact of COVID-19 on Russia}

COVID-19 was first transmitted to Russia by tourists returning from abroad. The lack of the quarantine measures in the first weeks of the outbreak allowed the virus to spread, especially in large cities. Russia faced the consequences of COVID-19 in the second half of March 2020.

Travel agencies, the hospitality industry, and retail trade in Russia were affected by the pandemic from February 2020 on. Lockdowns added to the list of the economic areas significantly affected by the spread of COVID-19. The sectors affected were transportation, leisure and entertainment, sports, public catering, domestic services (repair, laundry, dry cleaning, hairdressing, and beauty salons), non-food retail trade, stomatology, private education, and mass media. ${ }^{1}$ The decline in economic activity resulted in an unemployment increase from 4.7 percent in March to 5.8 percent in April with a smooth growth to 6.4 percent in August and a slow decline to 5.9 percent in December (see Figure 19.1).

Small business suffered dramatically from the quarantine, and the support measures resulted in a budget revenue decrease. These declines showed up in consolidated (regional plus local) budget revenues in Q2-Q3 of 2020. On the other hand, online retail and delivery increased in volume, while advertising then shifted from city streets to the internet. According to the research agency Data Insight, the number of orders in online stores in 2020 increased by 78 percent and reached 830 million. In monetary terms, these orders increased by 47 percent to 2.5 trillion rubles. In 2020, the share of online trade reached 9 percent of all Russian retail. ${ }^{2}$

The ripple effect of COVID-19 has had a number of economic and social impacts on the RF. The decline in oil prices also led to a decrease in federal budget revenues. As a response, the additional federal expenses and transfer payments to the regions from the federal budget were covered by the Reserve Fund of the government of the RF.

The World Bank has predicted a 6 percent drop in GDP in Russia as a result of the pandemic (World Bank 2020). The Rosstat - Russia's statistics bureau - was more

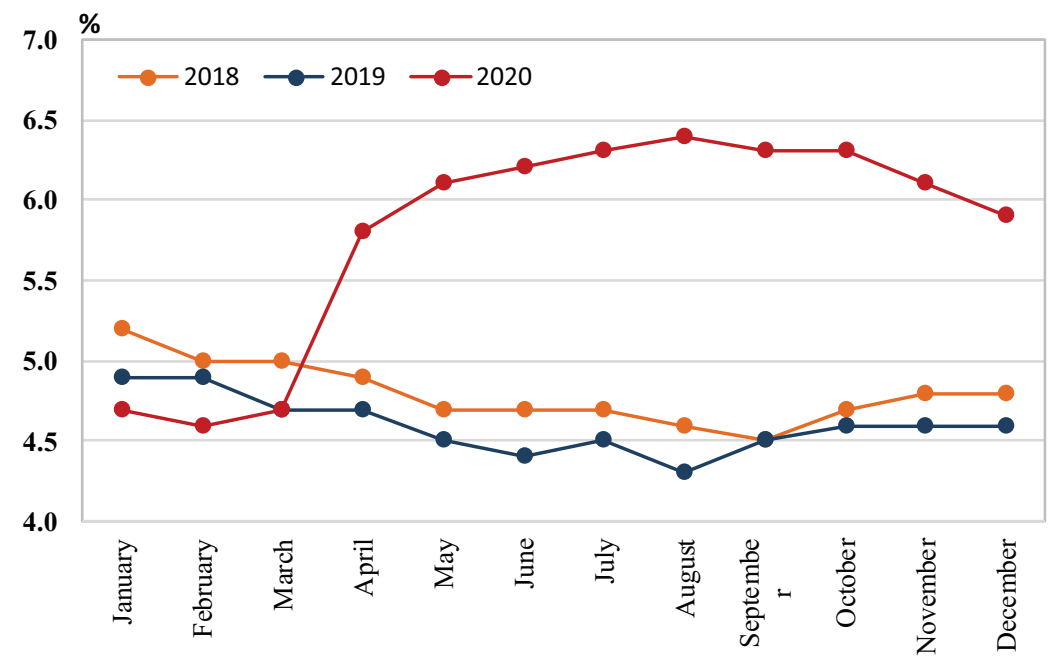

Figure 19.1 Monthly Unemployment Rate in Russia from 2018 to 2020 (According to the Methodology of the WTO) (Operational Data) (Percentage). 
optimistic: it listed a 3.1 percent decline in $2020 .^{3}$ The decrease in GDP in 2020 was a result of the restrictive measures introduced to combat COVID-19 infection and the decrease in global energy demand. The value-added component has significantly reduced in service industries: hotels and restaurants (-24.1 percent), cultural and sports institutions ( -11.4 percent), transport enterprises $(-10.3$ percent), organizations that provide other services to the public $(-6.8$ percent). Unfavorable export conditions and lower energy prices contributed to the decline in the value-added physical volume index (-10.2 percent). Increased demand for financial services led to a value-added increase in finance and insurance sphere (+7.9 percent). The increase in Housing and Utilities tariffs affected the value-added deflator indices of enterprises providing electricity, gas and steam (+3.9 percent), water supply, sanitation, and waste disposal (+6.2 percent). The growth of the value-added deflator index compared to last year in health care $(+11.9$ percent) and other sectors of the public administration are associated with an increase in the average salary in these industries.

The population of the RF has decreased by 510,400 people $(0.3$ percent of the total population) by the end of the year. ${ }^{4}$ In addition to the increase in mortality, many families postponed their childbirth decisions that will have negative effect in the future. Furthermore, it is unknown how the necessary shift to online education during shutdown will affect the future workforce.

The labor market has also changed. According to Ministry of Labor ${ }^{5}$ data, about 3.7 million Russians work remotely in 2020, which is about 7 percent of all employed citizens of the country. That number increased 110 times from previous year.

Despite the all measures taken by the all levels of government, this was not sufficient to stop the epidemic although in the summer the number of cases reduced. However, in the fall, the number of cases grew again (see Figure 19.2).

As of 31 December 2020, the number of total COVID-19 cases from the beginning of the year was 3,159,297 people (2 percent of the total population of the RF).

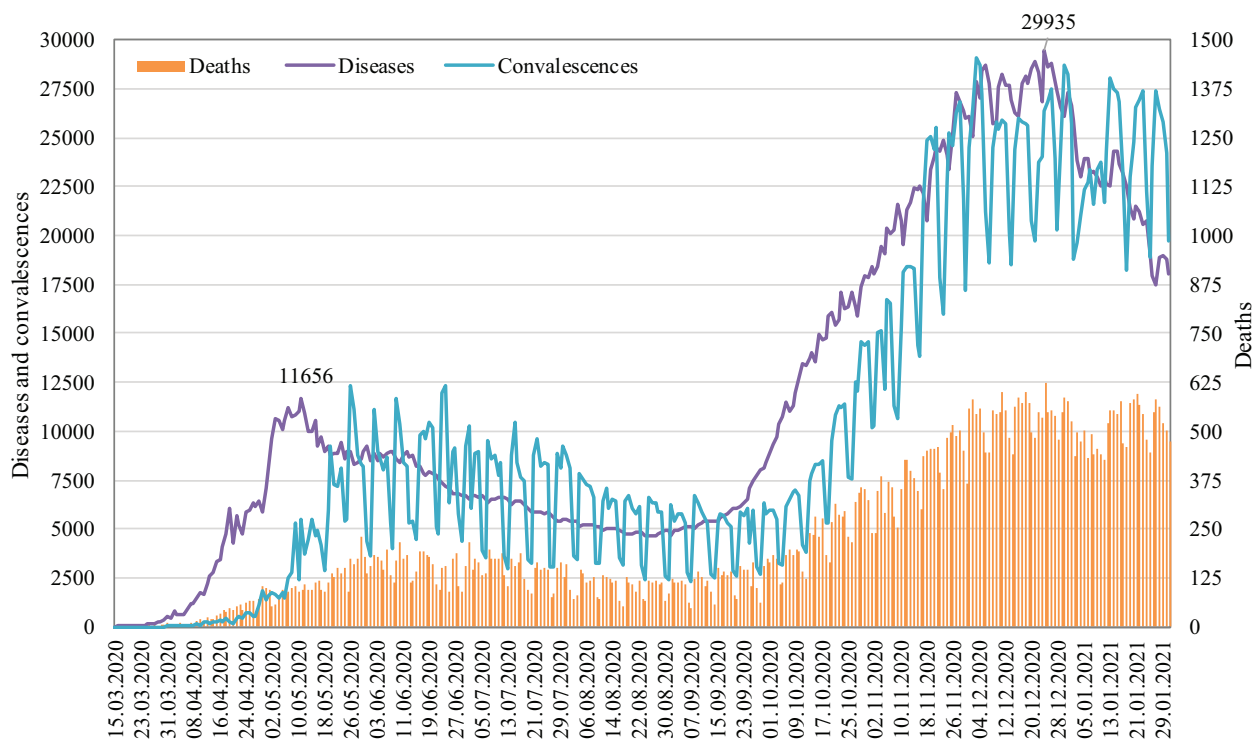

Figure 19.2 Daily Dynamics of Diseases (Cases), Recoveries (Convalescences), and Deaths from COVID-19 in Russia. 
The number of deaths reached 57,019 (0.04 percent of the total population). The daily numbers of new cases have grown dramatically from September. The disease's peak (29,935 people per day) was passed on 24 December 2020, and the number of cases has started to decrease.

The numbers of cases and deaths per 100,000 people varies considerably between regions (see Figure 19.5 in the Annex). The highest death rates to the number of people infected by COVID-19 on 31 December 2020 are in the Republic of Dagestan (4.8 percent of all infected), Rostov Oblast (4.0 percent), and Perm Krai and Krasnoyarsk Krai $\left(3.7\right.$ percent). ${ }^{6}$

\subsection{COVID-19 and federalism in Russia}

\subsubsection{Administrative and territorial divisions}

According to the RF Constitution, Russia is a federal state. ${ }^{7}$ The Federation consists of 85 regions (subjects of the federation). Local self-government system is represented

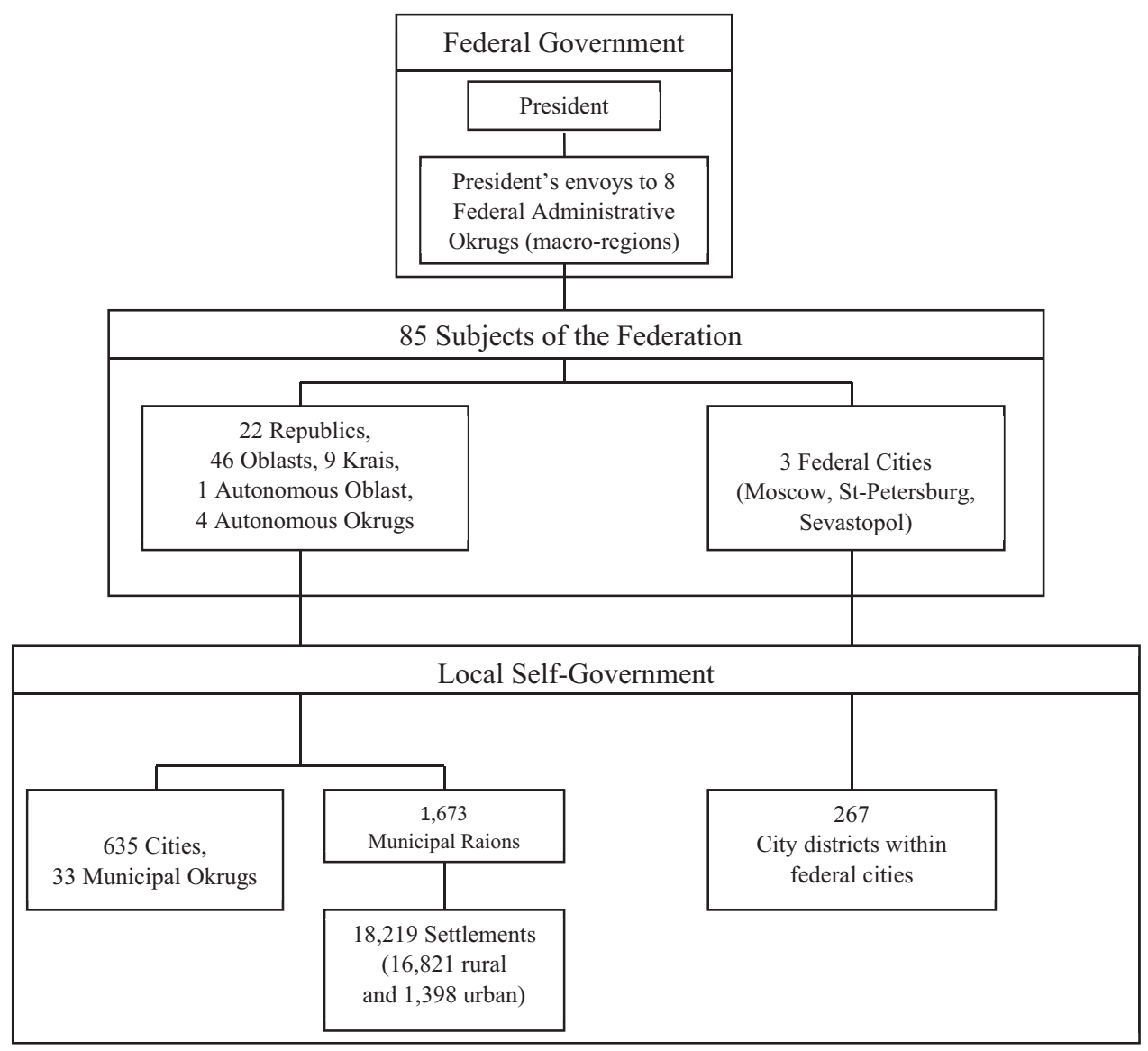

Figure 19.3 Russian Federation's Federal Structure.

Source: Updated from de Silva et al. (2009) based on Rosstat data on 1 January 2020. 
by 635 city municipalities (gorodskoi okrugs) and 33 municipal okrugs ${ }^{8}$ (both types are one-level local governments), plus 1,673 municipal raions ${ }^{9}$ with over 18,000 associated rural and urban settlements inside (two-tier local governments). ${ }^{10}$ Administratively, Russia is also divided into eight federal okrugs that are deconcentrated branches of the federal government (see Figure 19.3).

According to the new revision of the 2020 RF Constitution, federal territories (like territories in Canada) may be established in the RF. Russian legislation assigns powers and revenue sources across all levels of government. However, reassignment of revenues and expenditures during the last 15 years has made Russia a more and more centralized country. Besides, there is one phenomenon not typical in federal countries, namely "vertical of power." This vertical is exerted when regional governments have to account for their performance to the federal government, and local governments report to the regional ones. So, Russian intergovernmental relations usually are "top-down": thus, when the central government makes a decision, subnational governments have to agree and must try to perform according to those decisions.

This leads to the problem of accountability. The heads of the regions must look to the federal government for money and political survival. Thus, they are accountable upward and not downward, meaning that sometimes the federal orders are more important for regional governments than local needs.

Federal regulations often became unfunded mandates because of the lack of adequate resources transferred from the central level. In recent years, the heaviest mandates, such as raising wages in the public sector, were initially funded from the federal budget through grants to ensure a balance. After some time, funding for these items was stopped. In addition, the principles of distribution of these grants are not set up in legislation, unlike equalization grants.

\subsubsection{The Russian federation government's response to COVID-19}

In the middle of March 2020, a Coordination Council under the Government of the Russian Federation was formed to fight the spread of COVID-19 in the country. The Council's goal was to provide cooperation between the central government, governments of the subjects of the Russian Federation, local governments, and different organizations. Members of the Council discuss the effectiveness of the measures already taken to combat COVID-19 and the introduction of new ones.

The Government of Russia developed a "Priority plan." 11 This document contained a number of measures including provision of essential goods and services to the population, support for the sectors of economy at risk, support for small and medium business and other measures including extension of support to regional budgets faced with a decline in tax revenues.

The list of priority measures to ensure sustainable development of the economy included:

- Deferred payment of taxes and social contributions for certain categories of taxpayers;

- Suspension of audits and checks;

- Zeroing of customs duties for some socially important goods;

- Employment support; and

- Other targeted measures for certain sectors of the economy. 
For all small and medium enterprises (SMEs), a twofold reduction in the social contributions rate and loan restructuring was proposed.

Following the federal authorities, regional governments have also adopted measures to support economic activities. The most frequently used measures were:

- Reducing the property tax rate for taxpayers from the sectors of economy affected by COVID-19;

- Providing property tax benefits for landlords in exchange for rent reduction and/ or rent deferral for tenants;

- Reducing regional property rent;

- Reducing the rates of the SME taxes for certain sectors; and

- Canceling the transportation tax for certain sectors.

Local (municipal) governments took part in disinfection of public spaces, courtyards, public transport, ${ }^{12}$ and in some cases with the help of the reserve funds of local administrations (e.g., Podolsk, Smolensk, and Yakutsk) and control over the application of markings at retail outlets.

Besides, local governments allowed to defer payments for the lease of municipal property and local taxes.

Federal government social support measures included:

- Increasing the minimum sick leave payment for 2020;

- Increasing the unemployment benefit;

- Introducing additional benefit for an unemployed parent with children under 18;

- Additional one-time payments for families with children.

The Ministry of Healthcare ${ }^{13}$ and Federal Service for Surveillance on Consumer Rights Protection and Human Wellbeing (Rospotrebnadzor) ${ }^{14}$ plays a pivotal role in anti-epidemic response. The latter has regional offices, which include scientific research institutes, hygienic, and epidemiological centers and laboratories. The Ministry of Healthcare has adopted the "Interim methodical recommendations prevention, diagnosis and treatment of new coronavirus infections (COVID-19)" that have become the guideline for the regional health care authorities in their response to the pandemic.

The existing federal legislation gives the regional governments the power to establish restrictive measures in emergency situations. ${ }^{15}$ The Presidential Decree issued on 2 April $2020^{16}$ declared that regional governors have the power to implement any additional anti-COVID-19 restrictive measures to expand the federal ones. However, some regional governors (e.g., the head of Moscow) introduced restrictive measures even before the Presidential Decree was issued. Experts say that the Presidential Decree "transformed the opportunity into a duty." Presidential Decree also implies a personal responsibility of governors for the epidemic situation in regions. As a result, regional governors started to impose strict restrictions, often excessive ones (such as the prohibition against walking outdoors in Moscow that negatively affected the health of older people), so that the federal center could not accuse them for the insufficient measures.

All regional authorities eventually introduced a state of high alert. The first to do so were the regions in the Far East: Amur Oblast (27 January 2020), Jewish 
Autonomous Oblast (5 February 2020), the Republic of Buryatia (10 February 2020), and Yaroslavl Oblast (7 February 2020). In March, all other regions joined the list. The City of Moscow proclaimed a state of high alert on 5 March 2020. In St. Petersburg, Moscow, and Leningrad Oblasts, it was proclaimed on 13 March 2020. The last to do so was Voronezh Oblast (20 March 2020). ${ }^{17}$ In all, 43 regions out of 85 (including the City of Moscow, Moscow, and Leningrad Oblasts) declared a force majeure situation - the pronouncement of the existence of a crisis or disaster often called "an act of God."

The first self-quarantine order was introduced in the City of Moscow on 26 March 2020 and Moscow Oblast on 29 March 2020. By the end of March, 26 regions had adopted self-isolation measures. In the summer, most of the restrictions were canceled. However, in October, some isolation measures were reimposed. In spite of all the measures taken by all levels of government, this was not sufficient to stop the epidemic (see Figure 19.2).

As a result of the economic support measures (mostly tax deferrals), during the first half of the year, the main sources of regional budget revenues declined predictably. ${ }^{18}$ Profit tax revenues dropped 15.2 percent from the corresponding period of the previous year, personal income tax revenues decreased by 2.7 percent, small business taxes declined by 12.8 percent, and property taxes by 7.7 percent. The only increase was 3.2 percent in excise taxes. The steep drop in consolidated regional budgets revenue was made up for by a 57.4 percent growth in transfer payments from the federal budget. The federal government increased in grants by 64.1 percent, subsidies by 82.6 percent, and other intergovernmental transfer payments by 52.1 percent.

But, by the end of 2020, the deferrals were over, the economy began to recover, and the volume of tax and non-tax revenues of consolidated regional budgets almost returned to the level of 2019 (see Figure 19.6 in the Annex for monthly dynamics). Tax revenues from consolidated regional budgets shrank to 98.2 percent of those in $2019 .{ }^{19}$ Personal income tax rose by 7.5 percent from the corresponding period of the previous year, excise taxes by 5.6 percent, property taxes by 0.5 percent. Small business taxes declined by 0.7 percent. A 12.8 percent drop was seen in the profit tax. The largest profit tax revenue decline was in the regions with a high share of the oil and gas sector as well as the extraction and processing of metals in the industry. In the regions with a diversified economy, however, there was an increase in total tax revenues (this took place in 22 regions, including Tambov, Voronezh, Amur, Leningrad, and Tver Oblasts).

Transfer payments from the federal budget grew by 53.9 percent in 2020: grants were enlarged by 41.1 percent, subsidies by 81.6 percent, and other intergovernmental transfer payments by 48.5 percent.

Other tools for supporting subnational budgets were the loans from the federal budget. In December, the Ministry of Finance provided 224 billion rubles of budget loans maturing no later than 1 July 2021. These loans were available to 75 regions (Russian Ministry of Finance 2021).

Federal tax and non-tax revenues have fallen by 12.5 percent in 2020 compared to 2019. For that reason, all additional federal budget expenses (including intergovernmental transfer payments, see Table 19.2 in the Annex) were covered from the Reserve fund of the Government of the Russian Federation.

Federal transfer payments for supporting the implementation of anti-COVID-19 measures in 2020 account for 15 percent of consolidated regional budget expenditures 
on health care and 6 percent of consolidated budgetary and extra-budgetary health care expenses (Consolidated Budgets of the Russian Federation 2021).

\subsubsection{Assignment of powers in health care}

In 2001, the federal government launched intergovernmental relations reforms based on the fiscal federalism development strategy. ${ }^{20}$ The main objectives of these reforms were the following:

- To clarify and optimize the assignment of expenditure responsibilities across tiers of government;

- To eliminate unfunded federal and regional mandates;

- To reassign revenue sources to levels of government in accordance with their newly reassigned expenditure responsibilities;

- To establish transparent and fair rules for allocating federal and regional intergovernmental transfer payments. ${ }^{21}$

The new rules have been in effect since 2005. However, a transparent system of intergovernmental relations did not last long.

Soon numerous amendments were made to the laws that contradicted the original strategy of federalism. New federal unfunded mandates have appeared in the legislation, the change in the assignment of revenue sources did not fully correspond to the change in the allocation of expenditures and part of intergovernmental transfer payments became untransparent.

After the intergovernmental relations reforms, health care was funded by the level of government according to the type of services (2005-2011). Primary health care and ambulances were the responsibilities of the local governments, regional governments were in charge of the specialized health care in hospitals, and R\&D and specialized expensive treatment were assigned to the federal level.

Since 2012, the legislation has changed: provision of medical (including emergency) and palliative care have been assigned according to the ownership of the medical organization. Now, the federal government is responsible for the health care provided in federal hospitals while regional governments are responsible for all types of health care provided in regional hospitals and policlinics (Figure 19.4). ${ }^{22}$ Some regions delegate primary health care to the local level if local governments have their own health care institutions. ${ }^{23}$ According to the federal legislation, local self-government bodies just have to ensure the availability of medical care without an obligation to provide services.

Most health care services are funded by extra-budgetary Mandatory Medical Insurance Funds. ${ }^{24}$

Federal Mandatory Medical Insurance Fund (FMMIF) revenues include the following:

- Employer's insurance payments (5.1 percent of payroll) for the working population;

- The contribution from regional budgets for the non-working population (children, elderly people, and unemployed citizens);

- Specific purpose intergovernmental transfer payments from the federal budget. 
Federal programs

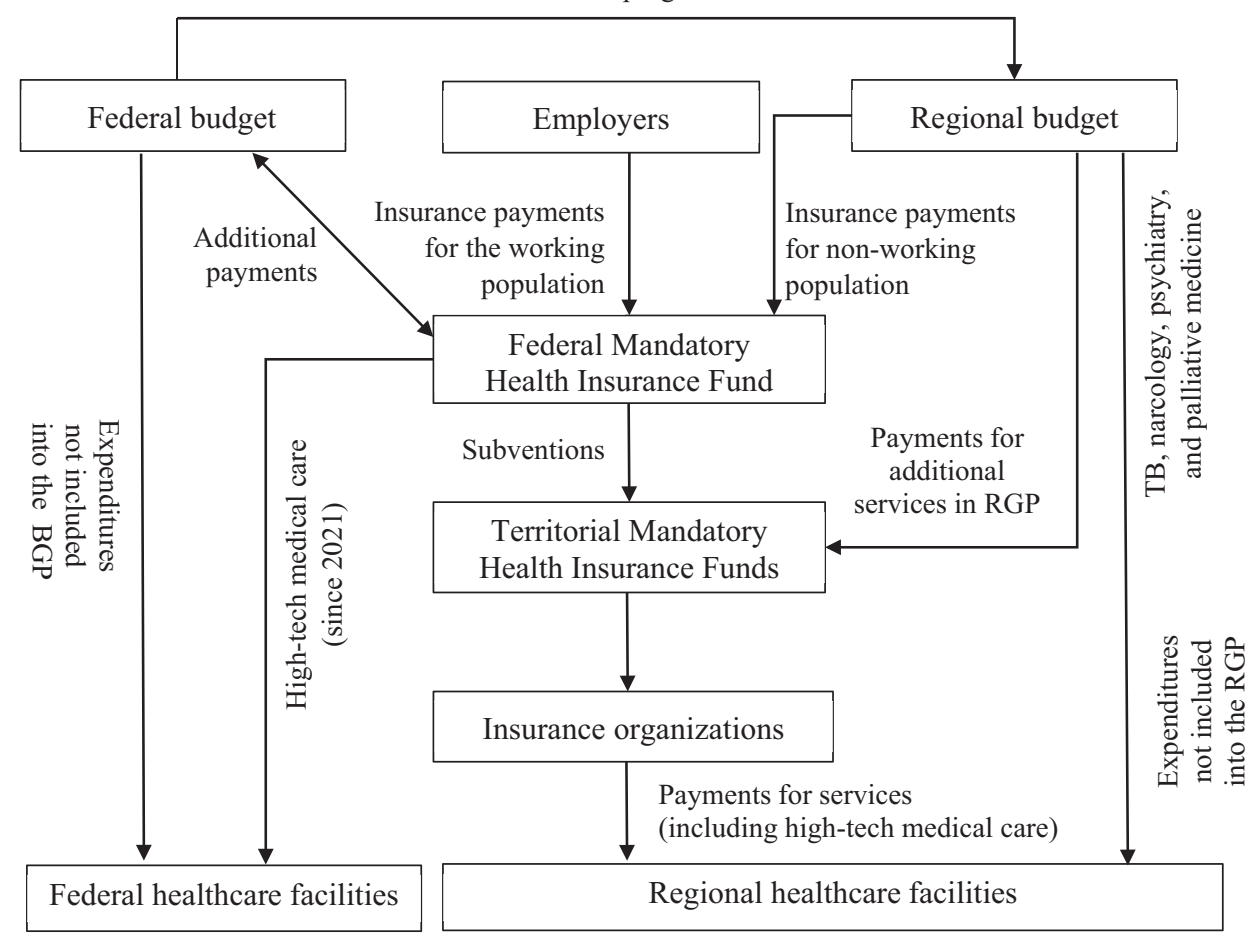

Figure 19.4 Public Financing of Healthcare Services in Russia.

Source: Author's sources, based on RF legislation and budget execution reports.

A total of 95 percent of the FMMIF budget is spent on transfer payments to the Territorial Mandatory Medical Insurance Funds (TMMIF). The allocation of these targeted subsidies to the TMMIF is based on a per capita amount and adjusted to account for the regional cost of living.

FMMIF also issues regulations on the management of public health care sector in regions. FMMIF and TMMIF pay for services included into the Basic Guarantee Program (BGP) on providing medical assistance to the residents of particular region. Regional governments may also include additional services into the Regional Guarantee Program (RGP) and finance it through the transfer from the regional budget to the TMMIF. Regions also finance tuberculosis, narcology, psychiatry, and palliative medicine.

In 2019, 60 percent of health care expenditures have been contributed by the Medical Insurance Funds, about 30 percent from the consolidated regional budgets and only 10 percent from the federal level (final expenditures without intergovernmental transfer payments) (Russia Federal Treasury 2021). In 2020, the figures were 50 percent, 37 percent, and 13 percent, respectively.

Total health care expenditures (budgetary and extra-budgetary) grew from 3.5 percent of GDP in 2019 to 4.6 percent of GDP ${ }^{25}$ in 2020 (at the same time GDP decreased 
by 3.1 percent). Most of the additional expenses associated with COVID-19 were carried out through regional budgets. Consolidated regional health care budgetary expenditures grew by 71 percent in 2020 while TMMIF expenditures increased by only 10 percent.

\subsubsection{COVID-19 impact on the RF health care system}

The Russian health care system was not prepared for the pandemic. The recent financial crisis and the growth of regional debts impacted the subnational governments' capacity to combat COVID-19. The effect of the previous economic shocks meant that the RF had to enact austerity measures across the regions that were called cost optimization programs. These programs involved stringent planning and approval processes for regional government from the federal Ministry of Finance. All regions receiving equalization grants had to prepare and approve such programs. One of the outcomes of the program was the optimization of the network of health care institutions and the reduction of the number of hospital beds.

Donor regions were also forced to optimize health care spending because of changes in the system of financing expenditures through the FMMIF. The health care financing became more even due to changes in the allocation formula. The new distribution formula was based on a per capita sum, adjusted for regional cost of living coefficients. Equalization resulted in the redistribution of FMMIF resources from "rich" to "poor" regions. Therefore, "rich" regions like "poor" ones had to optimize their medical institutions to make the health care sector more economically efficient.

Therefore, when faced with the first wave of COVID-19, the health care system began to adjust the number of hospitals and hospital beds to the new requirements. The federal structure of the state provides some leeway, allowing the regions to choose the way of adjusting, whether it is building new temporary or permanent hospitals or changing an existing hospital's profile or capacity.

For example, a new infectious disease hospital was built in the Republic of Tatarstan (a donor region), a hospital from prefabricated modules was constructed in only 55 days in Bashkortostan. In the City of Moscow, temporary hospitals were opened in the Trade Center "Moscow" and at the VDNKh exhibition center. The federal government helps to increase the number of beds with special grants (see Table 19.2 in the Annex).

Besides the insufficient number of beds, previous health care reforms resulted in the lack of doctors and nursing staff in the public sector. Some regions (e.g., Nizhny Novgorod Oblast and Republic of Tatarstan) successfully used the help of volunteers in organizing information about patients. ${ }^{26}$ District doctors received statistics from ambulance, call centers, and social workers - statistics that were processed by these volunteers. This information helped in making decisions about the urgency of assistance and the need for hospitalization.

With a lack of professionals, telemedicine began to play a significant role. Regional hospitals had online consultations with the specialists from the federal medicine centers.

Unfortunately, another impact on the health care system during the pandemic was a reduction in providing health services in other areas. One of the orders from the Ministry of Health ${ }^{27}$ recommended postponing planned medical care and suspending regular medical examinations. 


\subsection{Case study of innovation/transformations in COVID-19 and federalism in Russia}

\subsubsection{Fiscal policy}

According to Russian laws, regional governments have to follow the federal government's orders. However, the pandemic dramatically changed the fiscal policy goals.

Before 2020, subsidized regions had to adopt expenditure optimization and revenue increasing programs to receive equalization grants. Now, due to an increase in the number of disease cases, regional governments had to change policy guidelines. Regions had to increase health care expenses to open new inpatient or mobile hospitals, redesign existing ones, and attract additional personnel.

Following the federal recommendations, regional governments started to provide tax benefits for the small business and hard-hit economic sectors. So, budgetary policy has turned from saving costs and generating the highest possible revenues to increasing health care expenses and reducing budgetary income in the short term in order to save the tax base for the future.

Russia experienced a re-assignment of powers in the middle of 2000 s and a gradual move to a less transparent governance system. Surprisingly, in the aftermath of this less than clear health care expenditure allocation, public health care is still able to provide services and still works normally in practice. The existing health care system de facto assigns the responsibility for providing most of the services to the subnational levels of government.

The federal government supports regions in their fight against COVID-19 in three ways:

1 Through in-kind purchasing and distributing equipment and supplies among the regions - including ambulances, medical personal protective equipment, medical ventilators, ECMO equipment, and medicines (see Kurlyandskaya 2020);

2 Through intergovernmental transfer payments; and

3 Through short-term loans from the federal budget.

However, regional governments do not know how long this support will last. For example, how long will the federal budget fund additional payments to doctors and nurses working in hospital with COVID-19? The regions already had a negative experience when the central government stopped providing transfer payments for financing the obligations established by the federal legislation after a couple of years. This practice turned an obligation into an unfunded mandate. ${ }^{28}$ This uncertainty provides for a murky and potentially inconsistent policy environment for providing these essential services and is a concern for regions and significantly, for citizens. Besides, as often happens with emergency grants, new intergovernmental fiscal transfer payments are non-transparent. The results of the allocation of transfer payments are set by legislation but not the formulas. For example, three regions (Ivanovo Oblast, Murmansk Oblast, and Kabardino-Balkar Republic) received special ad hoc transfer payments (see Table 19.2 in the Annex).

A high degree of centralization in emergency management looks like an effective measure. However, Russia is a very centralized country, so further centralization is not necessary. On the contrary, it would be positive to see the regions 


\section{Nataliya Golovanova}

freer in decision-making as it were in mid-2000th and not overloaded with federal mandates. Nevertheless, the world pandemic is not a good moment for the redistribution of powers. Many are of the opinion that, if the system 'isn't broke, don't fix it.'

\subsubsection{New practices}

Several new features have appeared in the practice of Russian health care after the COVID-19 pandemic began.

First of all, temporary and mobile hospitals were built. It became clear that having permanent beds reserve for the case of emergency in stationary hospitals was too expensive. So light and mobile constructions helped to decide this problem for the required period.

One of the problems with COVID-19 is the lack of specialists (doctors and nurses) who could work with infected people. Life has shown that public health care needs more general practitioners because not all specialists can change their profile. This problem was partly solved with the help of volunteers and by hiring personnel from the private sector.

Besides, the pandemic gave a push to the use of telemedicine. Online conferences with professors from federal medicine centers also helped to develop the course of treatment in difficult cases.

The common threat also pushed interregional horizontal cooperation. Groups of doctors from hospitals in regions most successful in treatment (like Ta$\operatorname{tarstan}^{29}$ ) visited neighboring regions and the former CIS countries to share their experience.

Different initial conditions and different strategies for fighting COVID-19 led to different results. The numbers of infections and deaths per 100,000 people vary considerably (see Figure 19.5 in the Annex). This is especially noticeable when comparing the two regions with the highest death rates per 100,000 people, Moscow and St.

Petersburg. Both cities faced a high number of cases due to population density and intensive tourist traffic through the airport at the beginning of the epidemic. But St. Petersburg's death rate for the number of people infected by COVID-19 is more than twice as high as that in Moscow.

The COVID-19 infection has a seasonal spread, so in the fall, the number of cases and deaths began to grow. But now, both federal and regional governments can consider the previous experience and change policies so the next wave will be less damaging. The Ministry of Health also hopes that vaccinations, which began in December 2020 , could help to reduce the spread of the disease. 


\section{Annex}

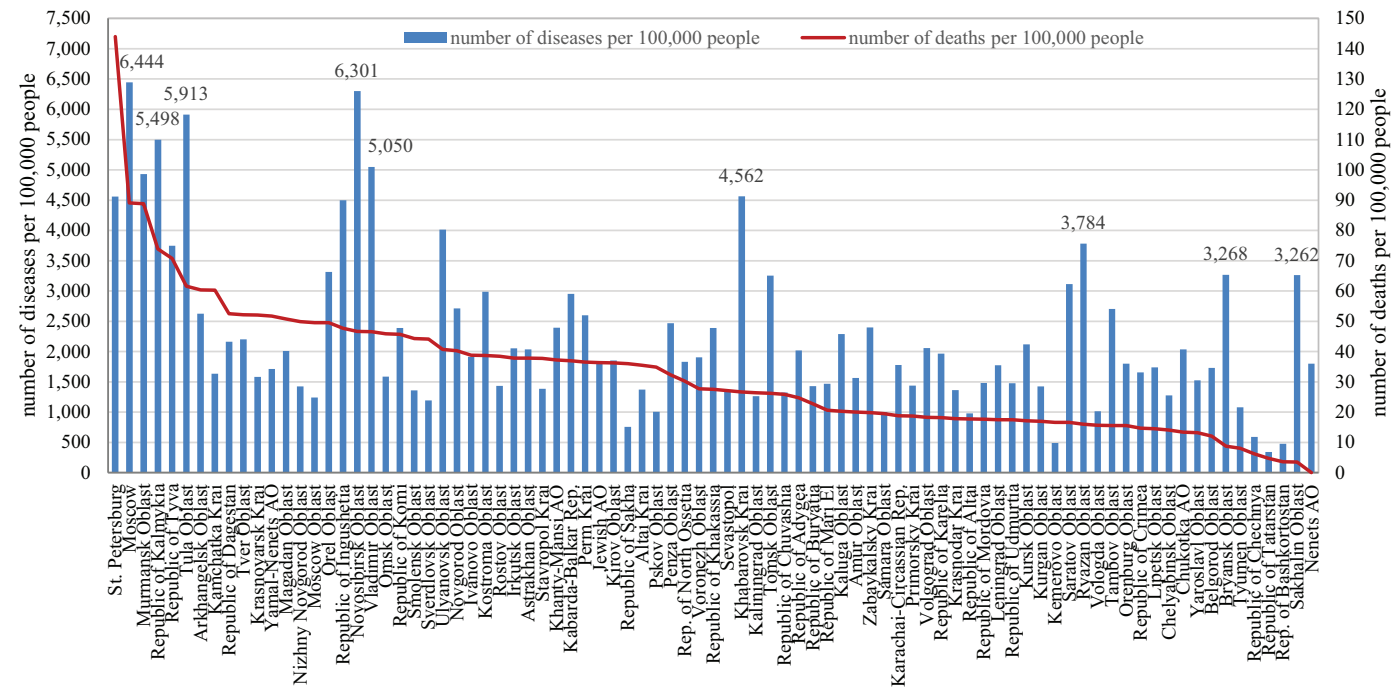

Figure 19.5 Number of COVID-19 Cases (Diseases) and Deaths by Regions as of 31 December 2020. Data source: Yandex DataLens, 2021. All Known Cases in Russia [dataset]. Available from: https://datalens.yandex/covid19 [Accessed 1 February 2021].
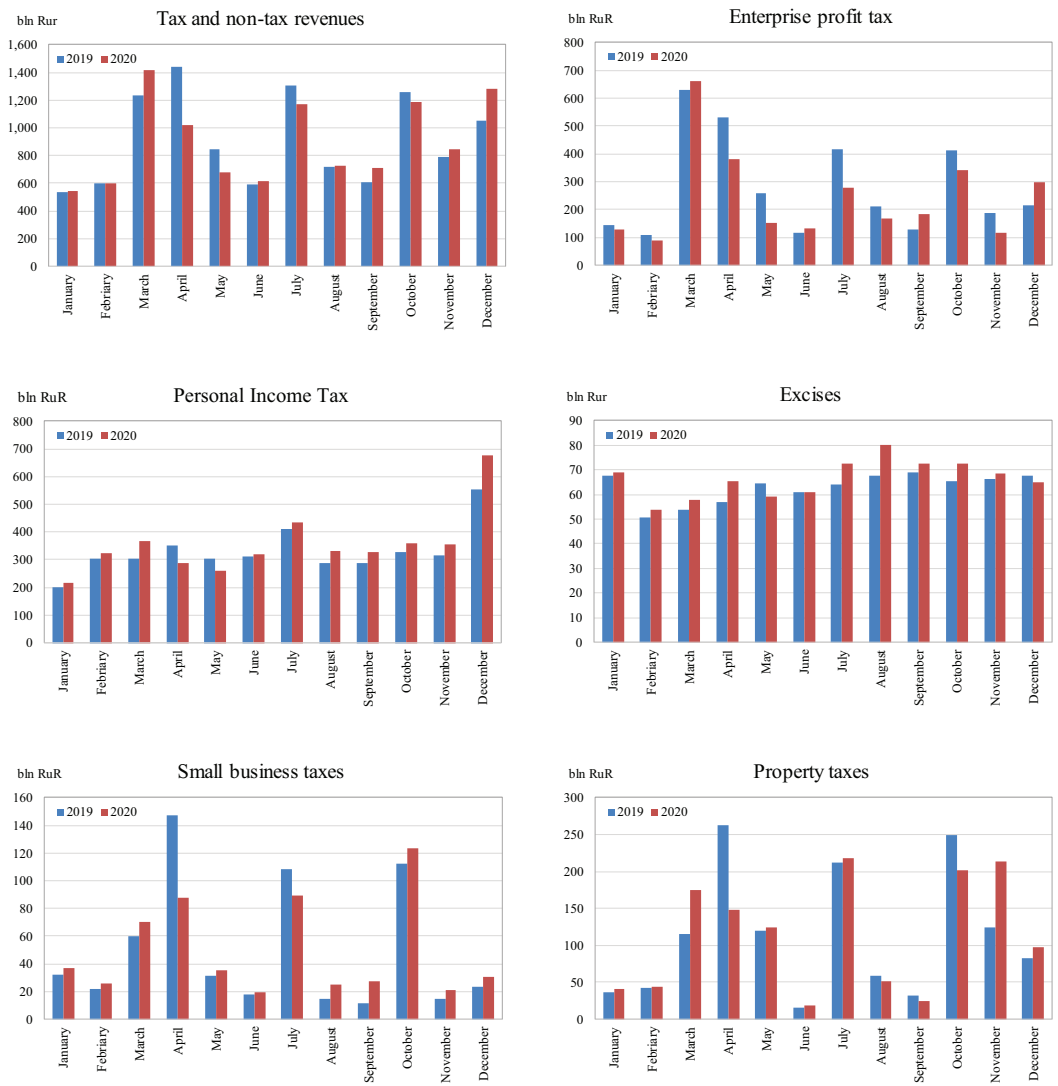

Figure 19.6 Consolidated Regional Budgets: Tax Revenues in 2019-2020. Data source: consolidated budgets of Russian Federation reports https://roskazna.gov.ru. 
Table 19.2 Additional Intergovernmental Transfer Payments Financed through the Reserve Fund of the Government of the Russian Federation in 2020

Budgeted, Million Rubles

1 Grants to support balanced budgets for equipping (re-equipping) 68,180 additionally created or re-profiled beds in medical organizations to provide medical care for patients with the COVID-19 infection

2 Grants to support measures to ensure balanced budgets that offer additional payments to medical and other workers of medical and other organizations providing medical care for the diagnosis and treatment of a new COVID-19 infection in contact with patients who have the COVID-19 infection

3 Grants to support measures to ensure the balance of budgets for the financial support of measures to combat the COVID-19 infection

4 Grants to support the balance of budgets for the provision of subsidies to legal entities and individual entrepreneurs to partially compensate for the costs associated with their activities in the context of a worsening situation as a result of the spread of the COVID-19 infection, including for maintaining employment and remuneration of their employees

Intergovernmental transfers for the purchase of drugs for the treatment of patients with the COVID-19 infection receiving medical care on an outpatient basis

6 Intergovernmental transfers for the implementation of incentive payments for the performance of especially important work to medical and other workers directly involved in the provision of medical care to citizens who have the COVID-19 infection

7 Intergovernmental transfers for the implementation of incentive payments for special working conditions and additional workload for medical workers providing medical care to citizens who have the COVID-19 infection and people at risk of contracting the COVID-19 infection

Intergovernmental transfers for the implementation of incentive payments for special working conditions and additional workload for employees of stationary social service organizations, stationary departments created in non-stationary social service organizations, providing social services to citizens who have the COVID-19 infection, and people at risk of the COVID-19 infection

9 Intergovernmental transfers to equip laboratories of medical organizations with medical devices that carry out etiological diagnostics of the COVID-19 infection with nucleic acid amplification methods

10 Intergovernmental transfers to the budget of the Kabardino-Balkar Republic for co-financing the expenditure obligations arising from the implementation of measures to counter the spread of the COVID-19 infection

11 Subsidy to the budget of the Murmansk Oblast to co-finance the expenditure obligations for the deployment in the village Murmashi of the Kola District of the Murmansk Region of a pre-fabricated field hospital to provide medical care to patients with the COVID-19 infection

12 Subsidy to the budget of the Ivanovo Oblast to co-finance expenditure obligations for the deployment in the territory of the Ivanovo region of a pre-fabricated infectious diseases hospital with a bed capacity of 360 beds to provide medical care to patients with the COVID-19 infections Total
10,000

Source: http://budget.gov.ru accessed on 1 February 2020. 


\section{Notes}

1 RF Government resolution N 434 on 3 April 2020.

2 The research agency Data Insight, 2021. [website]. Available from:_https://datainsight.ru/ [Accessed 8 April 2021].

3 Rosstat presents the first GDP estimate for 2020. Available from: https://rosstat.gov.ru/ storage/mediabank/Ytm01G1M/GDP-2020-1.pdf [Accessed 8 April 2021].

4 Federal State Statistics Service, 2021. Estimate of the resident population as of 1 January 2021. Available from: https://rosstat.gov.ru [Accessed 8 April 2021].

5 Ministry of Labor and Social Protection, 2021 [website]. Available from: https://mintrud. gov.ru/ [Accessed 8 April 2021].

6 Yandex DataLens, 2021. All Known Cases in the World [dataset]. Available from: https:// datalens.yandex/covid19 [Accessed 8 April 2021].

7 Nevertheless, the old Federal Constitutional Law of December 17, 1997 N 2-FKZ "On the Government of the Russian Federation" stated that the Government of the RF was guided by the principles of federalism and separation of powers. The new Federal Constitutional Law of November 6, 2020 N 4-FKZ "On the Government of the Russian Federation" doesn't mention federalism at all.

8 A municipal okrug - a newly established - in 2019 - type of local government that includes several localities with common borders (usually city or town and its surrounding raion).

9 A raion (also rayon) is an administrative unit in rural areas typical for several post-Soviet countries.

10 For more on administrative divisions, such as regions and local self-government in Russia see: de Silva, Migara, Galina Kurlyandskaya, Elena Andreeva, Natalia Golovanova. Intergovernmental Reforms in the Russian Federation: One step forward, two steps back? Washington: The World Bank Press, 2009.

11 Russian Federation Government, 2020. COVID-19 Response in the Russian Federation. In: Russian Federation 2020. 17 March 17. Translated in United Nations, New York City. See also report prepared by Deloitte Consulting LLC: "Support measures for those affected by COVID-19". Available from: https://www2.deloitte.com/ru/en/pages/tax/ articles/podderzhka-economiki.html [Accessed 8 April 2021].

12 Monitoring and atlas, 2020. Regions, municipalities and local communities against COVID-19. All-Russian Congress of Municipalities. Available from: http://okmo.news/ event.php?42 [Accessed 7 May 2021].

13 Russian Ministry of Healthcare, 2021 [website]. Available from: https://minzdrav.gov.ru/ [Accessed 8 April 2021].

14 Federal Service for Surveillance on Consumer Rights Protection and Human Wellbeing. Available from: https://www.rospotrebnadzor.ru [Accessed 8 April 2021].

15 Federal law No. 68-FZ of 21 December 1994. Protection of the Population and Territories in Case of Natural and Man-made Disasters. Duma, Moscow. Translated in International Labour Organization, Geneva, Switzerland. Available from: https://www.ilo.org/ $\mathrm{dyn} /$ natlex/natlex4.detail?p_lang=en\&p_isn=93583 [Accessed 8 April 2021].

16 Decree of the President of the Russian Federation of 2 April 2020 N 239. Moscow. Translated in Washington, DC: Food and Agriculture Organization. Available from: http:// www.fao.org/faolex/results/details/en/c/LEX-FAOC194256/ [Accessed 8 April 2021].

17 All data on alert mode from Consultant Plus legislation database. Available from: http:// www.consultant.ru/online/

18 Monitoring of Russia's Economic Outlook No.13 (115) August 2020. Available from: https://www.iep.ru/en/publications/publication/monitoring-of-russia-s-economicoutlook-no-13-115-august-2020.html [Accessed 8 April 2021].

19 Data on consolidated budgets of RF reports. Available from: https://roskazna.gov.ru and http://budget.gov.ru [Accessed 8 April 2021].

20 Decree of the Government of the Russian Federation N 584 of August 8, 2001 "On the Program for the development of fiscal federalism in the Russian Federation for the period up to 2005."

21 For more on fiscal federalism reform in Russia, see: De Silva et al. (2009). 


\section{Nataliya Golovanova}

22 Federal law No. 323-FZ of 21 November 2011. "On the basics of public health protection in the Russian Federation."

23 This is the remainder of the system that was in effect in 2005-2011. In most regions, since 2012 , local health care institutions have been transferred to the regional level.

24 See more on financing health care in Russia and Medical Insurance Funds: Popovich, L., Potapchik, E., Shishkin, S., Richardson. E., Vacroux, A. and Mathivet, B., 2011. Russian Federation: Health System Review. Health Systems in Transition, 13 (7), 1-190. Available from: https://www.euro.who.int/en/countries/russian-federation/publications/russianfederation-hit-2011 [Accessed 8 April 2021].

25 Preliminary estimates.

26 The conference, "Pandemic 2020: Challenges, Solutions, Consequences." Available from: https://confpandemic.com/ [Accessed 8 April 2021].

27 Order of the Ministry of Health of Russia No. 198N, 19 March 2020. Translated in Commonwealth of Independent States, Moscow. Available from: https://cis-legislation.com/ document.fwx?rgn=123310 [Accessed 8 April 2021].

28 For example, financial support for families with children has been assigned to the regions since 2005 and for the first two years was financed through subsidies from the federal budget. However, since 2007, this intergovernmental transfer has been canceled although responsibility for the provision of appropriate benefits is still assigned to the regional authorities by federal legislation.

29 The Republic of Tatarstan was one of the regions that first faced COVID-19 infections. But thanks to good governance, Tatarstan had the lowest infection rate per 100,000 people on 31 December 2020.

\section{Bibliography}

Consolidated Budgets of the Russian Federation, 2021. Federal Budget Execution in 2021. Portal for the Russian Federal Budgetary System. Available from: http://budget.gov.ru [Accessed 8 April 2021].

De Silva, M., Kurlyandskaya, G., Andreeva, E. and Golovanova, N., 2009. Intergovernmental Reforms in the Russian Federation. One Step Forward, Two Steps Back? Washington: The World Bank Press.

Federal Constitutional Law No. 2-FKZ of 17 December 1997, "On the Government of the Russian Federation” (with Amendments and Addenda of December 31, 1997). Duma, Moscow. Translated in World Trade Organization. Geneva, Switzerland. Available from: https:// www.wto.org/english/thewto_e/acc_e/rus_e/WTACCRUS48_LEG_79.pdf [Accessed 8 April 2021].

Federal State Statistic Service, 2020. Estimate of Russia's GDP for 2020. The Russian Government. Available from: https://rosstat.gov.ru/storage/mediabank/Ytm01G1M/GDP-2020-1. pdf [Accessed 8 April 2021].

Federal State Statistic Service, 2021. Estimate of the Resident Population of the Russian Federation. The Russian Government, 1 January. Available from: https://rosstat.gov.ru [Accessed 8 April 2021].

Kurlyandskaya, G., 2020. Federalism and the COVID-19 Crisis: 'Emergency Federalism' Russian Style. Forum of Federations. Available from: http://www.forumfed.org/2020/05/ federalism-and-the-covid-19-crisis-federalism-and-the-covid-19-crisis-emergencyfederalism-russian-style/ [Accessed 8 April 2021].

Monitoring of Russia's Economic Outlook No.13(115), August 2020. Gadar Institute for Economic Policy, Moscow. Available from: https://www.iep.ru/en/publications/publication/ monitoring-of-russia-s-economic-outlook-no-13-115-august-2020.html [Accessed 8 April 2021].

Russia Federal Treasury, 2021. Consolidated Budgets of the Russian Federation. The Russian Government. Available from: https://roskazna.gov.ru [Accessed 8 April 2021]. 
Popovich, L., Potapchik, E., Shishkin, S., Richardson. E., Vacroux, A. and Mathivet, B., 2011. Russian Federation: Health System Review. Health Systems in Transition, 13 (7), 1-190. Available from: https://www.euro.who.int/en/countries/russian-federation/publications/ russian-federation-hit-2011 [Accessed 8 April 2021].

Russian Federation Government Resolution N 434 on 3 April 2020. Commonwealth of Independent States, Moscow. Available from: https://cis-legislation.com/document. fwx?rgn=125277 [Accessed 8 April 2021].

Support measures for those affected by COVID-19. Deloitte Consulting LLC. 2021. Available from: https://www2.deloitte.com/ru/en/pages/tax/articles/podderzhka-economiki.html [Accessed 8 April 2021].

World Bank, June 2020. Global Economic Prospects. Washington. doi: 10.1596/978-1-46481553-9. Available from: https://www.vsemirnyjbank.org/ru/publication/global-economicprospects [Accessed 8 April 2021]. 